$\xi=$ 不

\title{
Geotechnical properties of lateritic soil as subgrade and base material for road construction in Abeokuta, Southwest Nigeria
}

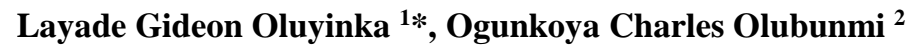 \\ ${ }^{1}$ Department of Physics, Federal University of Agriculture Abeokuta \\ 2 JAFAD College of Health Technology, Oru Ijebu, Nigeria \\ *Corresponding author E-mail: layadeoluyinka018@gmail.com
}

\begin{abstract}
Lateritic soils that overburden Mohammad Buhari Estate in Abeokuta area of Ogun State, Nigeria is in great use for road construction. However, little is known of their geotechnical properties and suitability as base, sub-based and sub-grade materials for road construction. This study is aimed at utilizing in accordance with regulatory standards of Nigeria, the geotechnical techniques to investigate the properties of this lateritic soil. The samples were collected at $0.25 \mathrm{~m}$ deep at different locations and were subjected to the following laboratory test; Particle size analysis, Atterberg limits test, Compaction test, Californian Bearing Ratio test, Moisture content and Specific gravity test. The result shows un-soaked CBR test from 12.52-55.84 \%. The specific gravity results range from 2.57-2.89 while the optimum moisture content and maximum dry density range from $18.20-28.30 \%$ and $1.48-1.81 \mathrm{mg} / \mathrm{m}^{3}$ respectively. The liquid limit, plastic limit and plastic index ranges from 12.0 to $40.1 \%, 10.0$ to $22.0 \%$ and 2.8 to $20.4 \%$ respectively. This implies that lateritic soil present throughout the study area is suitable for use as sub-base and base materials since the geotechnical properties are fairly within the regulatory standards of Nigeria.
\end{abstract}

Keywords: California Bearing Ratio; Laterite; Sub-Base; Base Materials; Specific Gravity Test.

\section{Introduction}

Lateritic soils have wider applications in the Nigerian construction industry, especially in road-construction projects where they are utilized as fill materials and flexible pavement foundations. Their usage as sub-base and base construction materials is mainly because they are easy to manipulate on the road surface and have natural stable grading with a suitable proportion to act as binders. One of the major causes of a road accident is a bad road which is usually caused by wrong application of constructional materials, especially laterite as base and sub-base material by construction companies (Oke et al., 2009a; Nwankwoala et al., 2014).

For a material to be used as either a base course or sub-base course depends on its strength in transmitting the axle-load to the sub-soil and or sub-grade (the mechanical interlock). The degree of success in each case depends on the genetic characteristic of the soils and the specific purpose for which they have been used. The performance of lateritic soils as foundations for structure is varied and appears to depend on the nature of the soil, the degree of the weathering, topography, the drainage condition and more importantly on the type of foundation, and the amount of loads imposed (Ojo etc. al, 2016).

In lateritic deposits, it may be possible to build ordinary structure on suitable design footings located a few feet below the ground surface. However, heavier structures may have to be based on firm layers, which are determined by sub-soil investigations. The actual design bearing values will depend on the degree of weathering of the lateritic soil and the geotechnical characteristics of the soil layers of a particular site. Lateritic soils develop from many rock types under different climatic and geochemical conditions. Hence in many instances, the properties to the parent materials are not lost on the resulting products of laterization. The process of laterization involves the breaking down of silicate materials such as illite and kaolinite leading towards the formation of hydrous oxides of iron and aluminum. The dominance of iron oxides gives laterites the characteristic reddish brown or dark brown color with a unique set of physical, chemical and engineering properties. (Madu, 1976).

The mineralogical composition of the lateritic soil has an influence on the geotechnical parameters such as specific gravity, shear strength, swelling potential, Atterberg limits, bearing capacity and petrograpic properties (Amadi et al., 2012). A literature review has revealed that the geo-technical characteristics and engineering behavior of red soils depend mainly on the genesis and degree of weathering (i.e decomposition, laterization, desiccation and hardening). Morphological characteristics as well as the type and content of secondary minerals are another genetic characteristic (Agbede, 1992). Good understandings of the basement soil on which highways and other transportation facilities are constructed are very important. Salter (1988) said the performance of a highway pavement is influenced to a very considerable extent by the sub-grade material.

Omotoso (2010) worked on laterite soil in connection with construction of road, highways and airfields. The engineering problems associated with lateritic soil were evaluated by Lyons et al. (1971). Balogun (1984) reported that the addition of lime to the soil increases its optimum moisture content, liquid limit, California Bearing Ratio (CBR) etc. In addition, Alao (1983) studied the engineering properties of some soil samples from Ilorin area and 
discovered that they could be stabilized by compaction and that the samples could yield maximum strength if they are compacted on the dry side of their optimum moisture content (OMC). Ogunsanwo (1989) evaluated CBR and shear strength of some compacted lateritic soils from southwestern part of Nigeria. He reported CBR of $27 \%$ in un-soaked and $14 \%$ for soaked sample for laterite soils derived from Amphibolites.

Furthermore, Oglesby and Kicks (1992) revealed that before 1920 attention was focused largely on the pavement surface, and little notice was given to the sub-base and base materials or to the way they were placed or compacted. Later, increased vehicle speeds brought demands for higher design that resulted in deeper cuts and higher fills. Therefore, the aim of this study is to investigate the properties of lateritic soil present in Mohammed Buhari Estate for road construction in Abeokuta and environs, southwest Nigeria.

\section{The location and geology of the study area}

\subsection{The location of the study}

The study area is located in Mohammad Buhari Estate in Abeokuta-North local government area, Abeokuta the capital of Ogun State, Nigeria. The area is accessed through Sagamu Abeokuta express road, Oke Mosan. It lies within longitude $03^{\circ} 21^{\prime} 54^{\prime \prime}$ E to $03^{\circ} 22^{\prime} 48^{\prime \prime} \mathrm{E}$ of the Greenwich Meridian and between latitude $07^{\circ} 9^{\prime} 38^{\prime \prime} \mathrm{N}$ to $07^{\circ} 10^{\prime} 22^{\prime \prime} \mathrm{N}$ of the Equator. Study sites constitute active burrow pit from which construction materials used for road works within Abeokuta are gotten. This burrow pit is chosen because of its usefulness in the construction of major highway across the state.

\subsection{The local geology}

The study area is dominated by Precambrian Basement Complex. In the Precambrian Basement Complex region, there are five major types of rocks identified which are;Migmatite-Gneiss Quartzite Complex, Slightly migmatised to un-migmatisedparaschist and metaigneous rock, Charnockitic rock, Older Granite, Minor Rock Types- Un-Metamorphosed dolerite dykes (Oluwafemi, 2012).Migmatite-Gneiss Quartzite Complexare the most widely spread in the basement complex of South-western Nigeria comprising; gneiss, quartzite and calc-silicate rockand marble. The gneiss consists of early gneiss, mafic-ultra mafic bands and granitic or felsic component. The migmatite-gneiss quartzite complex comprises of biotite and biotite gneiss, quartzite, quartz-schist and small lenses of calcisilicate rock (Oluwafemi, 2012).

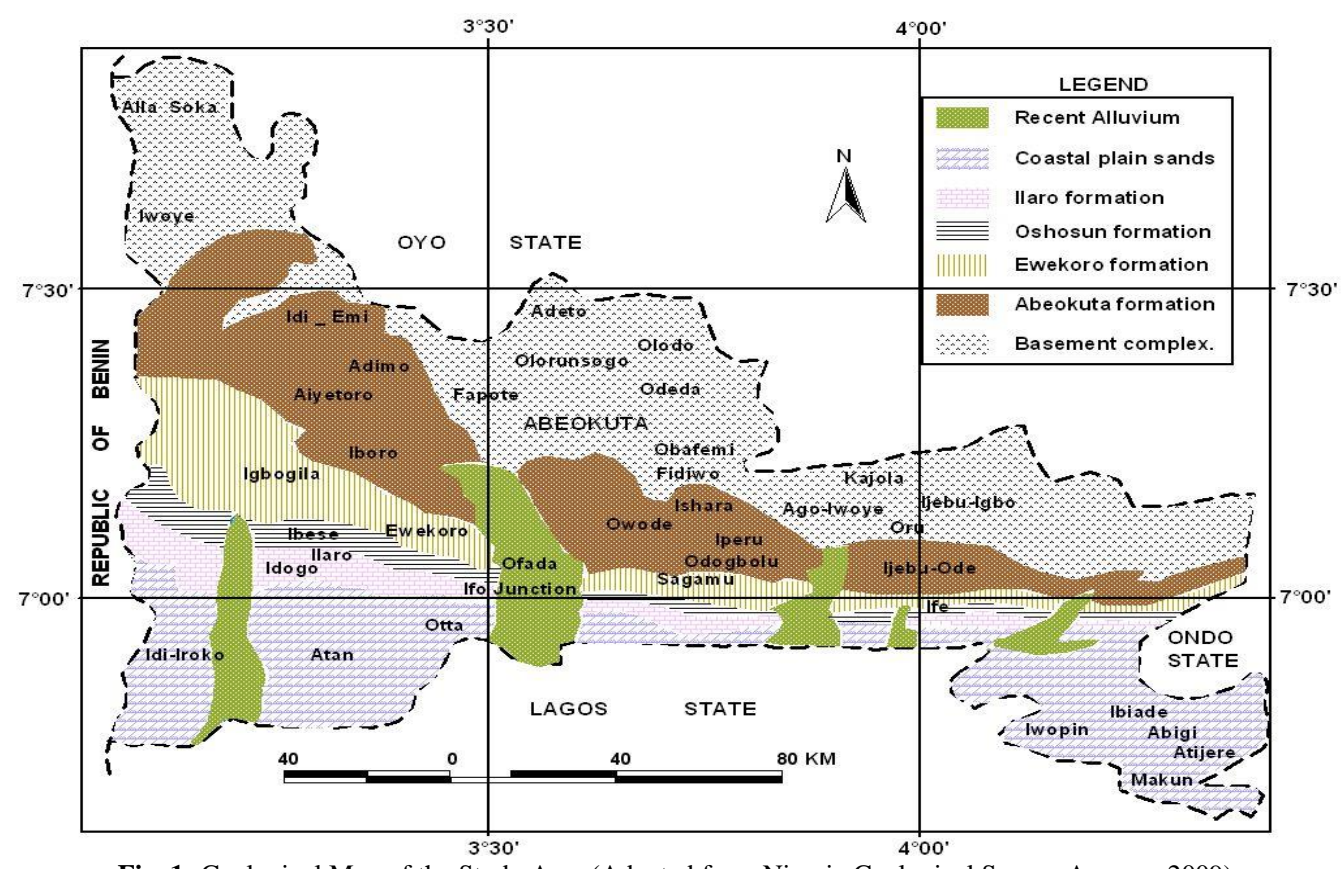

Fig. 1: Geological Map of the Study Area (Adapted from Nigeria Geological Survey Agency, 2009).

\section{Materials and methods}

The conventional tests for evaluation of soil suitability for engineering purposes were carried out on collected samples from the study area. Five representative samples were collected from $0.25 \mathrm{~m}$ deep. This was followed by oven-drying of the samples. Large soil particles (clods) in the sample were broken with a wooden mallet. The materials used during the collection of the samples were sample bags, Geographic positioning system (GPS), masking tape for labeling, marker for field indentation and soil auger. Laboratory procedures were followed in the determination of natural moisture content of the samples. Thereafter, several of the required geotechnical analyses were carried out. These include particle size analysis. Atterberg limits test, standard compaction test and the California Bearing Ratio (CBR) test.

\section{Results and discussion}

The result of the laboratory analyses are summarized in Table 1 while Table 2 shows the summary of results analysis as compared with Nigeria Standard of soil classification for roads and bridges in accordance to Federal Ministry of Works and Housing (1997) specification.

\subsection{Particle size analysis}

The particle size distribution analysis shows the range of particle sizes presents in the soil. According to the Federal Ministry of Work and Housing specification requirement, for a sample to be used for road construction, the percentage by weight passing the No. 200 sieves shall be less than but not greater than $35 \%$. Sequel to the above, the samples under review were good samples because percentage by weight passing sieve No. 200 for the soil do 
not exceed $35 \%$ except the first sample as shown in Table 1 and figure 2 .

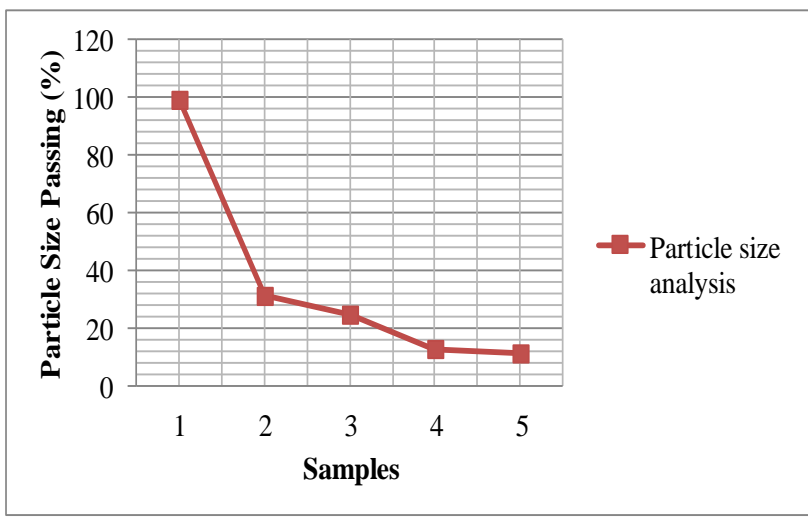

Fig. 2: Graphical Display of Particle Size Passing

\subsection{Atterberg limit test}

Figure 3 shows the liquid limits value, ranged from $12.0 \%$ to $40.1 \%$, the plastic limits varied from $10.0 \%$ and $22.0 \%$ while the plastic index is of the order of 2.8 to 20.4 (Table 1). Federal Ministry of Works and Housing (1997) for road works recommended liquid limits of $50 \%$ maximum for sub-base and base materials. All the studies soil samples fall within this specification, thus making them suitable for sub-grade, sub-base and base materials.

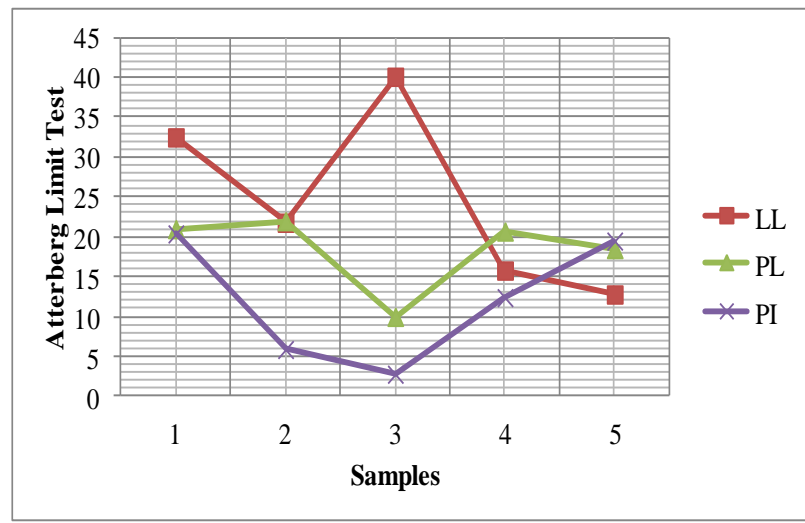

Fig. 3: Graph of Atterberg Limit Test for All Samples LL: liquid limit; PL: plastic limit; PI: plastic index;

\subsection{California bearing ratio $(\mathrm{CBR})$}

The CBR is a semi empirical test that is often employed in the estimation of the bearing capacity of sub-grade, sub-base and base materials (Simon et al. 1973 and Gidigasu, 1980). In figure 4, the unsoaked California Bearing Ratio (CBR) values for the lateritic soil sample range from $12.52 \%$ to $55.84 \%$. Federal Ministry of Works and Housing recommendation for soils for use as: subgrade, sub-base and base materials are: $\leq 10 \%, \leq 30 \%$ and $\leq 80 \%$ respectively for unsoaked soil. This implies that locations 1 and 2 with values less than $30 \%$ are excellent sub-base materials, locations 3,4 and 5 having values less than $80 \%$ are good base materials.All the locations have their unsoaked CBR value less than $80 \%$ which is the maximum value recommended for soils to be used as base materials (Federal Ministry of Works and Housing, 1997).

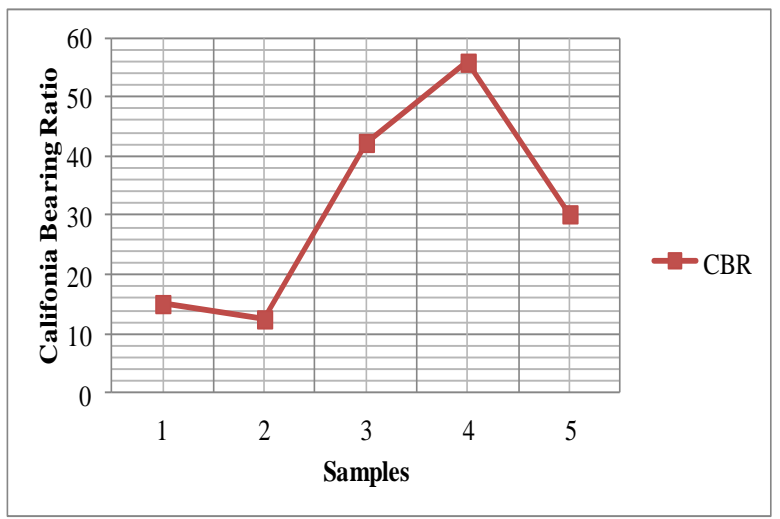

Fig. 4: Graphical Illustration of California Bearing Ratio.

\subsection{Compaction test}

This test is used to establish a dry density/moisture content relationship of a soil under controlled condition which can form a standard for comparison with field specifications. The Optimum Moisture Content (OMC) in figure 5 ranged between 18.2\% and $28.30 \%$ while that of maximum dry density for the samples varied between $1.48-1.81 \mathrm{mg} / \mathrm{m}^{3}$. According to O"Flaherty (1988) the ranges of values that may be anticipated when using the standard proctor test methods are: for clay, optimum moisture content (OMC) may fall between 20-30\% and MDD fall between 1.44$1.685 \mathrm{mg} / \mathrm{m}^{3}$. For silty clay OMC ranged between $15-25 \%$ and maximum dry density (MDD) fall between $1.6-1.845 \mathrm{mg} / \mathrm{m}^{3}$. For sandy clay, OMC between is 8 and $15 \%$ and MDD between 1.76$2.165 \mathrm{mg} / \mathrm{m}^{3}$. Thus, looking at the results of the soil samples, it could be noticed that they are clay and siltyclay.

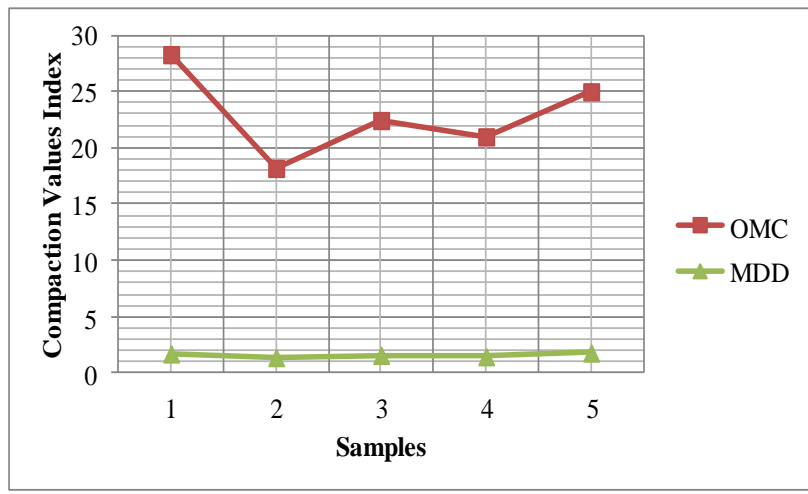

Fig. 5: Graph of Compaction Value Index.

OMC: Optimum Moisture Content; MDD-Maximum Dry Density

\subsection{Moisture content}

Figure 5 shows the moisture content of the samples ranges from $18.2 \%$ to $28.30 \%$ with an average value of 22.99 (Table 1) indicating that the soil is generally clayed and siltyclay (material passing sieve No. 200) and this finding is in agreement with other determined geotechnical parameters. Federal Ministry of Works and Housing (1972) for road works recommend liquid limits of 50\% maximum for sub-base and base materials. The results of the soil samples fall within allowed specification, thus making them suitable for sub-base and base materials.

\subsection{Specific gravity test}

The specific gravity of the soil depends on the amount of sand and also depends on their mineral constituents and mode of formation of the soil. The specific gravity for the studied soil samples ranged from 2.57 to 2.89 . According to specification, a good lateritic material should have specific gravity ranging from 2.5-2.75. Based on this fact, samples from the study area is considered to be 
acceptably high which may be attributed to high mineral composition of the samples.

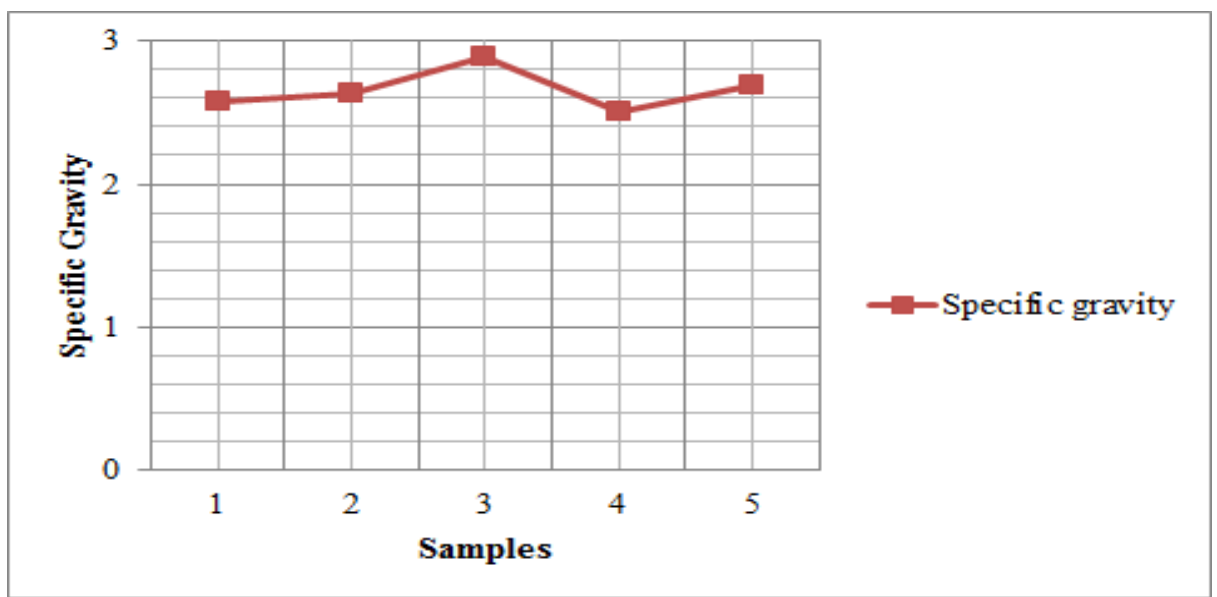

Fig. 6: Graphical Representation of Specific Gravity Test.

Table 1: Summary of Laboratory Results

\begin{tabular}{|c|c|c|c|c|c|c|c|c|c|}
\hline \multirow{2}{*}{$\begin{array}{l}\text { Samples } \\
\text { No. }\end{array}$} & \multirow{2}{*}{$\begin{array}{l}\text { Depth of samples } \\
\text { (m) }\end{array}$} & \multirow{2}{*}{$\begin{array}{l}\text { Particle size analysis (\%) } \\
\text { passing }\end{array}$} & \multicolumn{2}{|c|}{ Compaction test } & \multicolumn{3}{|c|}{ Atterberg limit } & \multirow{2}{*}{$\begin{array}{l}\text { Unsoaked } \\
\text { CBR }\end{array}$} & \multirow{2}{*}{$\begin{array}{l}\text { Specific } \\
\text { gravity }\end{array}$} \\
\hline & & & $\begin{array}{l}\text { OMC } \\
\%\end{array}$ & $\begin{array}{l}\text { MDD } \\
\mathrm{mg} / \mathrm{m}^{3}\end{array}$ & LL & PL & PI & & \\
\hline 1. & 0.25 & 99.32 & 28.30 & 1.73 & 32.50 & 21.00 & 20.40 & 15.10 & 2.57 \\
\hline 2. & 0.25 & 31.16 & 18.20 & 1.40 & 21.80 & 22.00 & 5.90 & 12.52 & 2.63 \\
\hline 3. & 0.25 & 24.64 & 22.45 & 1.60 & 40.10 & 10.00 & 2.80 & 42.30 & 2.89 \\
\hline 4. & 0.25 & 12.70 & 21.00 & 1.48 & 15.80 & 20.70 & 12.4 & 55.84 & 2.51 \\
\hline
\end{tabular}

LL: liquid limit; PL: plastic limit; PI: plastic index; OMC: optimum moisture content

Table 2: Summary of Results Analysis as Compared with Nigeria Standard of Soil Classification for Roads and Bridges

\begin{tabular}{|c|c|c|c|c|c|}
\hline Samples & 1 & 2 & 3 & 4 & 5 \\
\hline \multirow{2}{*}{ Particle size analysis } & 99.32 & 31.16 & 24.64 & 12.70 & 11.16 \\
\hline & Fail & Pass & Pass & Pass & Pass \\
\hline \multirow{2}{*}{ OMC } & 28.30 & 18.20 & 22.45 & 21.00 & 25.00 \\
\hline & Pass & Pass & Pass & Pass & Pass \\
\hline \multirow{2}{*}{ MDD } & 1.73 & 1.40 & 1.60 & 1.48 & 1.81 \\
\hline & Pass & Pass & Pass & Pass & Fail \\
\hline \multirow{2}{*}{ LL } & 32.50 & 21.80 & 40.10 & 15.80 & 12.80 \\
\hline & Pass & Pass & Fail & Pass & Pass \\
\hline PL & Pass & Pass & Pass & Pass & Pass \\
\hline \multirow{2}{*}{ PI } & 20.40 & 5.90 & 2.80 & 12.40 & 19.50 \\
\hline & Fail & Pass & Pass & Fail & Fail \\
\hline \multirow{2}{*}{ Specific gravity } & 2.57 & 2.63 & 2.89 & 2.51 & 2.69 \\
\hline & Good & Good & Poor & Good & Good \\
\hline \multirow{2}{*}{ CBR } & 15.10 & 12.52 & 42.30 & 55.84 & 30.25 \\
\hline & Pass & Pass & Pass & Pass & Pass \\
\hline Overall rating & Sub-base & Sub-base & Base & Base & Base \\
\hline
\end{tabular}

\section{Conclusion}

The geotechnical properties of lateritic soil in Mohammadu Buhari Estate, Abeokuta has been carried out in compliance with regulatory standard of Nigeria Federal ministry of Work and Housing (1972) for road construction. The result showed that the studied soil samples are classified as clay, silty clay easily compactable with good drainage. The soil samples tested from the study area indicate a general cohesive nature with low moisture content, high granular material, which is suitable for road construction. These valuable data obtained from the geotechnical analysis can be useful for civil engineers in the design and construction of roads in Abeokuta and environs for maximum durability and efficiency.

\section{Acknowledgments}

The authors appreciate the Department of Civil Engineering, Federal University of Agriculture Abeokuta where all the laboratory tests were carried out.

\section{References}

[1] Agbede, O.A. (1992). Characteristics of tropical Red soils as foundation materials, Nigerian Journal of Science, Vol. 26 pp 237-242.

[2] Alao, D. A. (1983) Geology and Engineering Properties of Lateritic Soil from Ilorin, NigeriaEngineering Geology, 19, 111-118. https://doi.org/10.1016/0013-7952(83)90029-7.

[3] Amadi, A. N., Eze, C. J., Igwe, C. O., Okunlola, I. A. and Okoye, N. O., (2012). Architect's and Geologist's view on the causes of building failures in NigeriaModern Applied Science,6 (6), 31-38.

[4] Balogun, L. A. (1984). Influence of geological origin on the geotechnical properties of lime-stabilized laterites. Proc., 8th Regional Conf. for Africa on Soil Mechanics and Foundation Engineering International Societyfor Soil Mechanics and Foundation Engineering, 1, 355-362.

[5] British Standard. B.S.1377 (1975): Method of Testing Soils for Civil Engineering Purpose, London British Standard Institution.

[6] Federal Ministry of Works and Housing (1997) General Specification for Roads and Bridges, Volume II, Federal Highway Department, FMWH: Lagos, Nigeria, 317 p. 
[7] Gidigasu, MD. (1976), "Laterite Soil Engineering", Elsevier, Amsterdam, 554p.

[8] Ogunsanwo, O. (1989). Some geotechnical properties of two Lateritic Soils compacted at different energies. Engineering Geology, 26, 261-269 https://doi.org/10.1016/0013-7952(89)90013-6.

[9] Nwankwoala, H.O. and Amadi, A.N. (2013), "Geotechnical Investigation of Sub-soil and Rock Characteristics in parts of ShiroroMuya-Chanchaga Area of Niger State, Nigeria. International Journal of Earth Sciences and Engineering, 6(1), 8- 17.

[10] Madu, R.M. (1976). An Investigation into the geotechnical and engineering properties of some laterites of Eastern Nigeria. Engineering Geology, 11: 101-125. https://doi.org/10.1016/00137952(77)90022-9.

[11] O'Flaherty, C. A., (1988). Highway Engineering Vol. 2, Edward Amold Publishers, London UK.

[12] Simon, A.B., Giesecke, J. and Bidlo, G (1973): Use of lateritic soil for road construction in North Dahomey, Engineerin Geology, 7:197-218. https://doi.org/10.1016/0013-7952(73)90031-8

[13] Ojo, G.P., Igbokwe, U.G., Nwozor, K.K. and Egbuachor, C.J. 2016 Geotechnical Properties of Lateritic Overburden Materials on the Charnockite and Gneiss Complexes in Ipele-Owo Area, Southwestern Nigeria American Journal of Engineering Research (AJER) Vol. 5, Issue-9, pp-53-59.

[14] Oke, S,A.,Okeke, O.E., Amadi, A.N. \& Onoduku, U.S. (2009), "Geotechnical Properties of the Subsoil for Designing Shallow Foundation in some selected parts of Chanchaga area, Minna, Nigeria", Journal ofEnvironmental Science, 1(1), 45 - 54

[15] Oluwafemi, O. 2012. Electrical resistivity imaging survey for shallow site investigation at University of Ibadan campus southwester Nigeria. ARPN Journal of Engineering and Applied Sciences. 7(2): 187-196.

[16] Omotoso, (2010). An Investigation into the geotechnical and engineering properties of some laterites of Eastern Nigeria Journal of Nigeria Mining Geology and Metallurgical Society, 1:10-110.

[17] Salter, R.J (1988). Highway design and construction, Macmillan education limited, London, pp. 341Oglesby, C.H and Hicks, R.G (1992). Highway Engineering, John Wiley and Sons, New York, $4^{\text {th }}$ edition, pp 847. 